Check for updates

Cite this: J. Mater. Chem. B, 2021, 9, 6226

Received 10th June 2021

Accepted 5th July 2021

DOI: $10.1039 / \mathrm{d} 1 \mathrm{tb} 01307 f$

rsc.li/materials-b

\section{Evaluation of cyclooxygenase-2 fluctuation via a near-infrared fluorescent probe in idiopathic pulmonary fibrosis cell and mice models $\uparrow$}

\author{
Yude Wang, $\ddagger^{a b c}$ Yinghui Wei, $\ddagger^{a b} \mathrm{Na} \mathrm{He}$, Liangwei Zhang, ${ }^{\mathrm{c}}$ Jinmao You, (D) \\ Lingxin Chen (iD *ce and Changjun Lv*ab
}

\begin{abstract}
Idiopathic pulmonary fibrosis (IPF) is a devastating and fatal interstitial lung disease due to various challenges in diagnosis and treatment. Due to its complicated pathogenesis and difficulty in early diagnosis, there is no effective cure. Cyclooxygenase-2 (COX-2) is inextricably associated with pulmonary fibrosis. The abnormal level of COX-2 leads to extremely exacerbated pulmonary fibrosis. Therefore, we reported a nearinfrared fluorescent probe $\mathrm{Cy}-\mathrm{COX}$ to detect the fluctuation of COX-2 levels during pulmonary fibrosis and explain its important protective effect. The probe Cy-COX showed a significant enhancement of fluorescence signal to COX-2 with excellent selectivity and sensitivity. In order to clarify the relationship between COX-2 and pulmonary fibrosis, we used the probe Cy-COX to detect COX-2 fluctuation in organisms with pulmonary fibrosis. The results showed that the COX-2 level increased in the early stage and decreased in the late stage with the aggravation of pulmonary fibrosis. Furthermore, up-regulation of COX-2 levels can effectively alleviate the severity of pulmonary fibrosis. Therefore, Cy-COX is a fast and convenient imaging tool with great potential to predict the early stage of pulmonary fibrosis and evaluate the therapeutic effects.
\end{abstract}

\section{Introduction}

Many diseases, including interstitial lung diseases (ILDs), accompanying various degrees of fibrosis, have high morbidity and mortality, including the well-known disease idiopathic pulmonary fibrosis (IPF). ${ }^{1,2}$ IPF is an interstitial disease with short-term functional deterioration and rapid progression. The overall prognosis of IPF patients is poor, with a 5 year survival, which is worse than several types of cancer. ${ }^{3}$ The pathogenesis of IPF is not yet fully understood, and there is still no unified

\footnotetext{
${ }^{a}$ Department of Respiratory Medicine, Binzhou Medical University Hospital, Binzhou 256603, China

${ }^{b}$ Medicine Research Center, Institute of Molecular Medicine, Binzhou Medical University, Yantai, 264003, China. E-mail: lucky_lcj@sina.com

C CAS Key Laboratory of Coastal Environmental Processes and Ecological Remediation, Shandong Key Laboratory of Coastal Environmental Processes, Yantai Institute of Coastal Zone Research, Chinese Academy of Sciences, Yantai 264003,China. E-mail: lxchen@yic.ac.cn, liangweizhang@yic.ac.cn

${ }^{d}$ Rehabilitation Center, Qilu Hospital, Cheelo College of Medicine, Shandong University, Jinan 250100, China

${ }^{e}$ The Key Laboratory of Life-Organic Analysis, Key Laboratory of Pharmaceutical Intermediates and Analysis of Natural Medicine, College of Chemistry and

Chemical Engineering, Qufu Normal University, Qufu 273165, China

$\dagger$ Electronic supplementary information (ESI) available. See DOI: 10.1039/ d1tb01307f

\# These authors contributed equally.
}

mechanism that can explain total pulmonary fibrosis, which may be caused by multiple factors. ${ }^{4}$ Therefore, early identification and determination of the process from pulmonary inflammation to pulmonary fibrosis may be of great significance in predicting disease progression and improving effective treatment. In addition, the transformation of myofibroblasts and the deposition after collagen synthesis during pulmonary fibrosis are important mechanisms for the pathogenesis of pulmonary fibrosis. ${ }^{5}$ Although nintedanib and pirfenidone are recognized as specific drugs of pulmonary fibrosis until now, none of them can cure pulmonary fibrosis. ${ }^{6}$ Therefore, there is an urgent need for the effective treatment of pulmonary fibrosis.

Cyclooxygenase (COX), known as prostaglandin endoperoxide synthase, represents COX-1 and COX-2, the two isoenzyme families. ${ }^{7}$ COX-1 is normally expressed in most tissues and is mainly involved in homeostasis. COX-2 is an inducible enzyme involved in the pathogenesis of many diseases, and it is almost not expressed in most normal tissues. ${ }^{8-12}$ However, it can be significantly increased by the stimulation of a variety of different mediators, including proinflammatory cytokines, fibrotic cytokines, hormones, and oncogenes. ${ }^{13,14} \mathrm{COX}-2$ is considered a potentially important medium in the fibrogenic process. Prostaglandin E2 (PGE2), an important metabolite of COX-2, has an important protective effect on pulmonary fibrosis. PGE2 
can inhibit the proliferation of fibroblasts, the transformation of myofibroblasts, the synthesis of collagen, and promote the degradation of newly synthesized collagen. ${ }^{15,16}$ Some previous research suggested that the deficiency of COX-2 led to the deterioration of pulmonary fibrosis. ${ }^{17-19}$ Therefore, the up-regulation of COX-2 will have an important therapeutic effect on pulmonary fibrosis. Until now, various methods of analyzing and detecting COX-2 have been developed, for example, western blot, RT-PCR, and immunohistochemistry. ${ }^{20-22}$ In contrast to these biological detection methods, which are complicated in operation and cannot be used for visual monitoring in living organisms, fluorescence probe-based visualization of pathophysiological changes in organisms is becoming increasingly indispensable. The collaborative work of fluorescent bioimaging technology and fluorescent probes has obvious advantages in non-invasive in situ rapid analysis, high selectivity, sensitivity, temporal and spatial resolution. ${ }^{23,24}$ Furthermore, near-infrared (NIR) fluorescence has the advantages of low background interference and deep tissue imaging, which greatly promotes in vivo imaging of molecular processes. ${ }^{25-30}$

Therefore, we preferred designing a fluorescent probe in the NIR region for imaging. Until now, several fluorescent probes for COX-2 have been developed, ${ }^{31-35}$ but the short excitation and emission wavelengths of the developed probes limit their application to a certain extent. Therefore, we designed a nearinfrared fluorescent probe Cy-COX to detect COX-2 changes in organisms during the process of pulmonary fibrosis. Cy-COX roughly includes three components: The indomethacin (IMC) is the response unit; The NIR heptamethine cyanine fluorophore is the fluorescence modulator; The response unit and the fluorescence modulator are connected by the hexanediamine. The response unit can specifically recognize COX-2 and turn on the fluorescence. In addition, the probe can detect COX-2 with high sensitivity and selectivity in cells. As far as we know, this is the first NIR fluorescent probe to visualize COX-2 changes in pulmonary fibrosis cells and mice models, which may provide powerful help for further research on the biological process of IPF.

\section{Experimental}

\subsection{Synthesis of probe Cy-COX}

Compound c (511.5 mg, $1 \mathrm{mmol}$ ), compound e ( $455 \mathrm{mg}, 1 \mathrm{mmol}$ ), and triethylamine $(101 \mathrm{mg}, 1 \mathrm{mmol})$ were successively added to the ethylene glycol methyl ether solution $(25 \mathrm{~mL})$. The above solution was placed in a dark environment and heated to reflux at $90{ }^{\circ} \mathrm{C}$ for $12 \mathrm{~h}$. After the mixture was concentrated, the crude product was purified by silica gel column chromatography $(10: 1$ $\left.\mathrm{CH}_{2} \mathrm{Cl}_{2} / \mathrm{CH}_{3} \mathrm{OH}\right)$ to give the blue probe $\mathrm{Cy}$-COX in $60 \%$ yield. ${ }^{1} \mathrm{H}$ NMR $\left(500 \mathrm{MHz}, \mathrm{CDCl}_{3}\right) \delta 8.63(\mathrm{~s}, 1 \mathrm{H}), 7.74-7.61(\mathrm{~m}, 4 \mathrm{H})$, 7.50-7.40 (m, 2H), 7.32-7.19 (m, 2H), 7.05 (dd, $J=9.3,5.0 \mathrm{~Hz}, 3 \mathrm{H})$, $6.86(\mathrm{dd}, J=27.2,8.5 \mathrm{~Hz}, 4 \mathrm{H}), 6.64(\mathrm{dd}, J=9.0,2.5 \mathrm{~Hz}, 1 \mathrm{H}), 5.56$ $(\mathrm{d}, J=12.2 \mathrm{~Hz}, 2 \mathrm{H}), 4.13(\mathrm{q}, J=7.1 \mathrm{~Hz}, 2 \mathrm{H}), 3.82(\mathrm{~d}, J=9.2 \mathrm{~Hz}, 6 \mathrm{H})$, $3.77(\mathrm{t}, J=6.8 \mathrm{~Hz}, 2 \mathrm{H}), 3.69(\mathrm{~s}, 2 \mathrm{H}), 3.26(\mathrm{dd}, J=13.0,6.7 \mathrm{~Hz}, 2 \mathrm{H})$, $2.50(\mathrm{t}, J=6.2 \mathrm{~Hz}, 4 \mathrm{H}), 2.39(\mathrm{~s}, 3 \mathrm{H}), 1.95-1.86(\mathrm{~m}, 2 \mathrm{H}), 1.81$ (dd, $J=12.7,6.4 \mathrm{~Hz}, 2 \mathrm{H}), 1.73$ (s, 4H), 1.59-1.48 (m, 3H), 1.43-1.27 $(\mathrm{m}, 10 \mathrm{H}), 1.26$ (t, $J=7.1 \mathrm{~Hz}, 3 \mathrm{H}) .{ }^{13} \mathrm{C} \mathrm{NMR}\left(126 \mathrm{MHz}, \mathrm{CDCl}_{3}\right.$ ) $\delta 170.99,168.35,161.95,161.67,156.07,139.42,136.44,133.46$, $131.08,130.95,130.81,130.54,129.09,128.70,117.61,115.29$, 114.91, 112.92, 111.68, 101.26, 55.63, 53.40, 52.26, 39.61, 39.32, $31.68,28.83,26.95,25.73,25.41,13.05$. MS $\left(\mathrm{ESI}^{+}\right): \mathrm{m} / \mathrm{z}$ $\mathrm{C}_{59} \mathrm{H}_{69} \mathrm{ClN}_{5} \mathrm{O}_{3}+$ calcd. 930.5083, found $\left[\mathrm{M}^{+}\right] 930.5267$.

\subsection{CCK-8 assay for Cy-COX}

To evaluate the cytotoxicity of the probe, CCK- 8 assays were carried out. MRC- 5 cells (8000 per cell) and RLE-6TN cells ( 8000 per cell) were seeded in 96 -well plates in $10 \%$ fetal bovine serum DMEM medium. The 96-well plate was placed in a $37{ }^{\circ} \mathrm{C}$, $5 \% \mathrm{CO}_{2}$ environment to make the cells adhere for $24 \mathrm{~h}$. Then the cells were incubated with $0,10,20,30,40,50,60,70,80$, and $100 \mu \mathrm{M}$ (final concentration) of Cy-COX for $24 \mathrm{~h}$. Then, the previous media was discarded, and $100 \mu \mathrm{L}$ medium containing $10 \%$ CCK-8 solution was added to each well. Then the absorbance at $450 \mathrm{~nm}$ was measured with a microplate reader after $30 \mathrm{~min}$. The control group eliminated the effect of DMSO. As shown in Fig. S4 (ESI $\dagger$ ), cells showed high vitality and indicated that our probe was safe for cell detection.

\subsection{Pulmonary fibrosis cell models}

MRC-5 and RLE-6TN cells were cultured in a serum-free DMEM medium, and transforming growth factor $\beta 1$ (TGF- $\beta 1$ ) was used to stimulate these two cells for $24 \mathrm{~h}$ and $72 \mathrm{~h}$ to establish cell models of pulmonary fibrosis. All cells were incubated with the probe at $37{ }^{\circ} \mathrm{C}$ for $60 \mathrm{~min}$ before imaging.

\subsection{Pulmonary fibrosis animal models}

Eight-week-old C57BL/6 mice obtained from Binzhou Medical College were selected for the experiment. The mice were allowed to eat food and water freely in the light/dark (12:12) cycle. To establish the pulmonary fibrosis mice model, bleomycin ( $\left.5 \mathrm{mg} \mathrm{kg}^{-1}\right)$ was injected into the trachea in a single dose under anesthesia and raised until the 28 th day.

\subsection{Imaging of mice and isolated organs}

The establishment of the mice model refers to the mice pulmonary fibrosis animal models. All the C57BL/6 mice in the experiment were instilled into the probe Cy-COX $(100 \mu \mathrm{M}$, $50 \mu \mathrm{L}$ in 1:9 DMSO/saline v/v) through the trachea. Mice in each group were anesthetized by intraperitoneal injection of $4 \%$ chloral hydrate $(0.2 \mathrm{~mL})$ before imaging. The organs of the mice were taken out for imaging of the isolated organs. The imaging of mice and isolated organs was performed using the in vivo imaging system with excitation wavelengths set at $650 \mathrm{~nm}$ and emission wavelengths at 750-800 $\mathrm{nm}$.

\subsection{Ethics statement}

Animal procedures were in agreement with National Guidelines for the Care and Use of Laboratory Animals. The experimental protocols were approved by the Institutional Animal Care and Use Committee in Binzhou Medical University. Approval Number: No. IRB2021-231. 


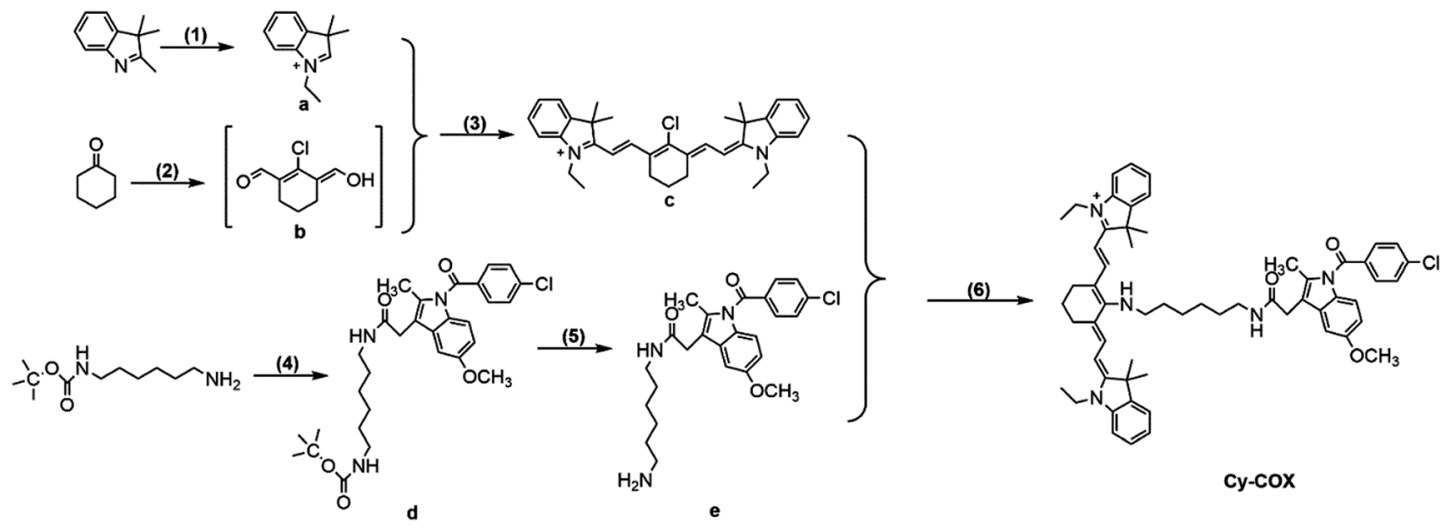

Scheme 1 (1) lodoethane, acetonitrile, refluxed, $12 \mathrm{~h}, 90 \%$; (2) DMF, $\mathrm{CH}_{2} \mathrm{Cl}_{2}, \mathrm{POCl}_{3}, 45{ }^{\circ} \mathrm{C}, 3 \mathrm{~h}, 85 \%$; (3) $n$-butyl alcohol : benzene = $7: 3$ (v/v), refluxed, $3 \mathrm{~h}, 70 \%$; (4) EDCl, $\mathrm{N}$-boc-1,6-hexanediamine, DMAP, indomethacin, room temperature, $24 \mathrm{~h}, 55 \%$; (5) trifluoroacetic acid, $\mathrm{CH}_{2} \mathrm{Cl}_{2}$, room temperature, $3 \mathrm{~h}$; (6) ethylene glycol methyl ether, refluxed, $12 \mathrm{~h}$.

\section{Results and discussion}

\subsection{Design strategies for probes Cy-COX}

We reported a novel "off-on" COX-2 specific fluorescent probe, and the details of the Cy-COX synthesis are illustrated in Scheme 1 . The synthetic routes of the compounds are discussed in the ESI. $\dagger$ Compounds were characterized by ${ }^{1} \mathrm{H}$ NMR, ${ }^{13} \mathrm{C}$ NMR, and MS. Fluorophores in the NIR region are widely used due to their high tissue permeability and low background signal. Therefore, a heptamethine cyanine dye (compound c, Scheme 1) with NIR fluorescence emission was chosen as a fluorophore for the COX-2 probe design. It has been shown that IMC can specifically bind hydrophobic pockets of COX-2 composed of Arg120, Tyr355, and Glu524..$^{36,37}$ Therefore, IMC
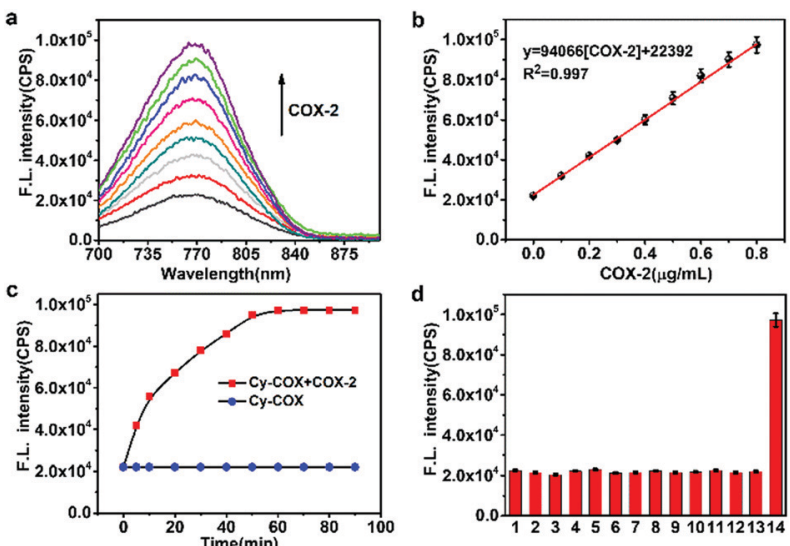

Fig. 1 Spectral and enzymatic properties of Cy-COX. (a) Spectral variation of $\mathrm{Cy}$-COX $(10 \mu \mathrm{M})$ after $60 \mathrm{~min}$ upon addition of COX-2 (0, 0.1, 0.2, 0.3, $0.4,0.5,0.6,0.7$, and $\left.0.8 \mu \mathrm{g} \mathrm{mL}^{-1}\right)$ in Tris $-\mathrm{HCl}(100 \mathrm{mM}, \mathrm{pH} 8.0)$ at $37^{\circ} \mathrm{C}$. (b) Linear fitting curve between the fluorescence intensity and COX-2 $\left(0-0.8 \mu \mathrm{g} \mathrm{mL}^{-1}\right)$. (c) Time-dependent fluorescence signal change of $\mathrm{Cy}$ COX toward COX-2 $\left(0.8 \mu \mathrm{g} \mathrm{mL}^{-1}\right)$. (d) Fluorescence responses of $\mathrm{Cy}$-COX $(10 \mu \mathrm{M})$ toward different biomolecules $\left(0.8 \mu \mathrm{g} \mathrm{mL}^{-1}\right)$ : 1, control; 2, DNA; 3, RNA; 4, BSA; 5 , histone; 6, hemoglobin; 7, lysozyme; 8, proteinase k; 9, collagen; 10 , triacylglycerol acylhydrolase; $11, \beta$-amylase; 12 , trypsin; 13 . chymotrypsin, and 14, COX-2. All data were obtained at $\lambda_{\mathrm{ex}}=650 \mathrm{~nm}$, $\lambda_{\mathrm{em}}=750-800 \mathrm{~nm}$. was selected as the COX-2 response unit. Then, linear alkyl diamines were selected to connect IMC and the fluorophore, one end of which formed an amide bond with IMC and the other end formed a secondary amine bond with the Cy7-Cl. Fluorescence quenching occurred due to the photoinduced electron transfer (PET) between the fluorophore and the response unit, ${ }^{33,35}$ and hence, the probe Cy-COX displayed weak fluorescence. In the presence of COX-2, probe Cy-COX can bind to Arg120, Tyr355, and Glu524 amino acids of COX-2, and the response unit IMC of Cy-COX can occupy the large hydrophobic cavity of the COX-2 homodimer. We also used the molecular docking method (Fig. S1, ESI $\dagger$ ) to confirm the proposed binding mode, which was consistent with the proven interaction between IMC and COX-2. We hypothesized that the probe Cy-COX can adopt an unfolded conformation to inhibit the PET effect. This unfolded conformation inhibited the PET effect and restored fluorescence. Finally, we obtained a NIR fluorescent probe, Cy-COX, which can specifically detect COX-2.

\subsection{Spectral properties}

The spectral properties of Cy-COX were determined in Tris-HCl buffer (100 mM, pH 8.0). The maximum absorption wavelength of Cy-COX $(10 \mu \mathrm{M})$ was at $630 \mathrm{~nm}$ (Fig. S3, ESI $\dagger)$. The maximum emission wavelength of the probe was also detected. As shown in Fig. 1a, the fluorescence emission centered at $770 \mathrm{~nm}$ gradually increased after adding COX-2 (from 0 to $0.8 \mu \mathrm{g} \mathrm{mL}{ }^{-1}$ ). In the given range, the fluorescence intensity at $770 \mathrm{~nm}$ formed a good linear proportional relationship with COX-2 concentration (Fig. 1b). The regression equation was $F_{770 \mathrm{~nm}}=94066[\mathrm{COX}-2] \mu \mathrm{g} \mathrm{mL} \mathrm{mL}^{-1}+22392$ $\left(R^{2}=0.997\right)$. The limit of detection $(3 \sigma / \kappa)$ towards COX-2 was determined to be $11 \mathrm{ng} \mathrm{mL}^{-1}$ under the given experimental conditions. The Fig. S11 (ESI $\dagger$ ) showed a comparison of the detection limit of our probe Cy-COX and other reported COX-2 probes. The results showed that Cy-COX was highly sensitive to COX-2. We also carried out dependent studies of the probe Cy-COX with COX-2. As shown in Fig. 1c, the increment of fluorescence intensity was dependent on the incubation time, and the fluorescence signal reached the maximum and was stable 

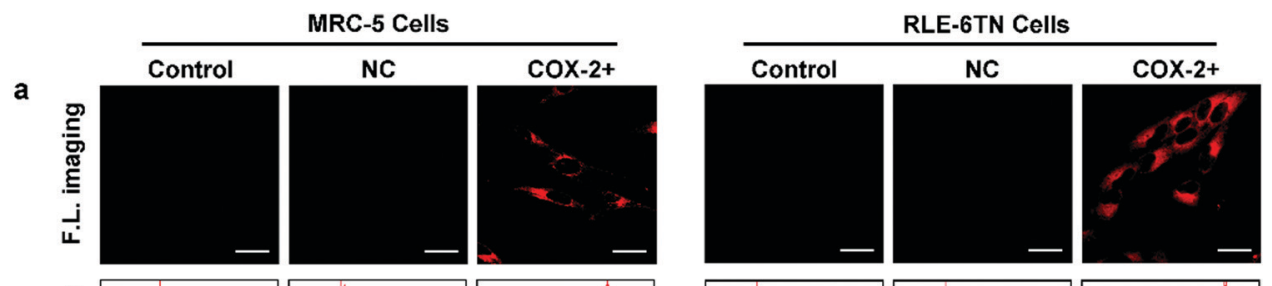

b
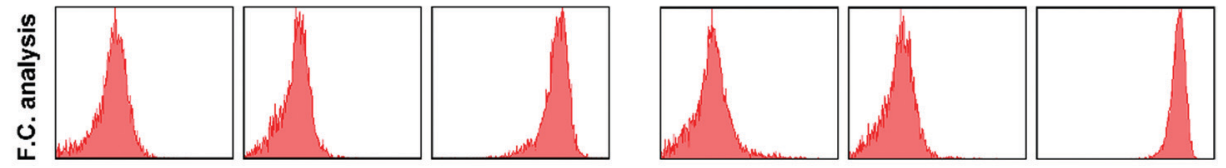

C

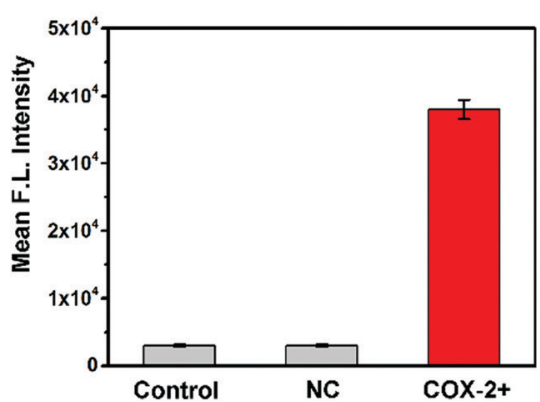

d

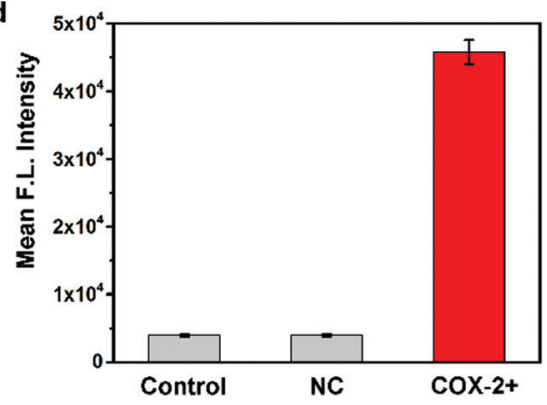

Fig. 2 The expression of COX-2 in living MRC-5 and RLE-6TN cells was analyzed by laser confocal microscopy and flow cytometry. (a) The cells were added with $\mathrm{Cy}-\mathrm{COX}(5 \mu \mathrm{M})$ and incubated for $60 \mathrm{~min}$ to serve as the control group. The same treatment was performed for all groups as the control group before imaging, and the negative control group (NC) group was transfected with empty plasmid PIRES2-EGFP, the COX-2+ group was transfected with PIRES2-EGFP-PTGS2 to overexpress COX-2. (b) The control group, NC group, and COX-2+ group were analyzed by flow cytometry. (c) Quantitative mean fluorescence intensity of MRC-5 cell images. (d) Quantitative mean fluorescence intensity of RLE-6TN cell images. Data are displayed as mean \pm SD $(n=5)$. Scale bars: $20 \mu \mathrm{m}$.

within $60 \mathrm{~min}$. There was no change in the fluorescence signal in the absence of COX-2. Therefore, Cy-COX was useful for the detection of COX-2 with high sensitivity, showing great potential in biological sample analysis.

\subsection{Selectivity of the probe Cy-COX}

Next, we examined the fluorescence signal change of Cy-COX to related molecules in Tris- $\mathrm{HCl}$ buffer $(100 \mathrm{mM}, \mathrm{pH}=8.0)$. In Fig. 1d, the probe Cy-COX did not show obvious fluorescence change in the presence of various biomolecules, such as DNA, RNA, BSA, histone, and so on. However, after exposure of Cy-COX to COX-2, the fluorescence intensity increased significantly. The selectivity of the probe to COX-1 and other related species is shown in Fig. S5 (ESI $\dagger$ ). These results indicated that Cy-COX had high selectivity, which motivated us to use Cy-COX to detect COX-2 changes in living organisms.

\subsection{Imaging of $\mathrm{Cy}$-COX response to $\mathrm{COX}-2$}

We first discussed the toxicity of the probe to living cells. We performed CCK-8 experiments to detect the toxicity of the probe at 0 to $100 \mu \mathrm{M}$ on MRC-5 and RLE-6TN cells. CCK-8 experimental results suggested that the probe Cy-COX with low cytotoxicity can be used for imaging living cells (Fig. S4, ESI $\dagger$ ). The cells were incubated with Cy-COX at $37{ }^{\circ} \mathrm{C}$ for $60 \mathrm{~min}$ before the imaging was conducted by laser scanning confocal microscope. MRC-5 and RLE-6TN cells were grouped according to the experimental design. As shown in Fig. 2a, there was no fluorescence in the Control and NC groups due to the low levels of COX-2 in normal MRC-5 and RLE-6TN cells. The fluorescence intensity of the COX-2+ group was significantly enhanced, which indicated that there was a higher level of COX-2. The results of the bright field image of cell imaging in Fig. 2a can be viewed in Fig. S6 (ESI $\dagger$ ). Furthermore, the results obtained by flow cytometry analysis (Fig. 2b) were consistent with the imaging results shown in Fig. 2a. The mean fluorescence intensities were directly quantified according to Fig. 2a and displayed in Fig. 2c and d, which inspired us to study the important role of COX-2 in physiological and pathological processes using our probe Cy-COX.

\subsection{Changes of COX-2 in pulmonary fibrosis cell models}

Now that it has been established that our probes can image COX-2 in cells, we began to explore the fluctuations of COX-2 in different stages of pulmonary fibrosis. We used TGF- $\beta 1$ ( $5 \mathrm{ng} \mathrm{m \textrm {m } ^ { - 1 }}$ ) to stimulate cells to establish pulmonary fibrosis cell models. Then, the probe Cy-COX was added to cells and incubated at $37{ }^{\circ} \mathrm{C}$ for $60 \mathrm{~min}$ before imaging. As illustrated in Fig. 3a, the control group expressed almost no fluorescence due to the low concentration of COX-2. After $24 \mathrm{~h}$ of TGF- $\beta 1$ stimulation, MRC-5 and RLE-6TN cells showed obvious fluorescence enhancement, indicating that the intracellular COX-2 level significantly increased. However, when the cells were stimulated for $72 \mathrm{~h}$, the fluorescence intensity of the cells obviously reduced, indicating that the levels of COX-2 reduced extremely. The flow cytometry results were consistent with the cell imaging results (Fig. 3b). Fig. 3c presented the mean 


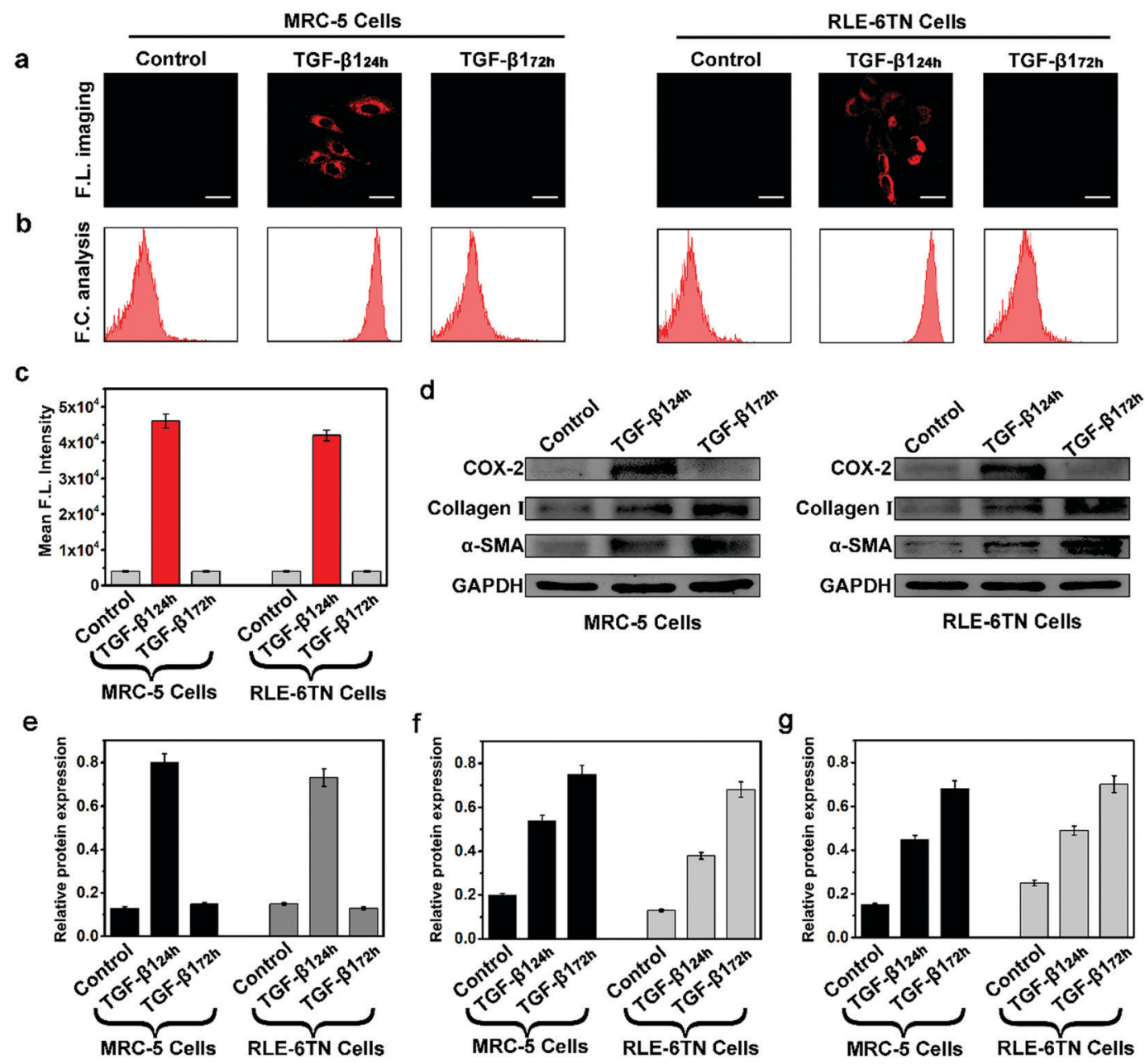

Fig. 3 The changes of COX-2 in MRC-5 and RLE-6TN cells in pulmonary fibrosis cell models at different time points: $24 \mathrm{~h}$ and $72 \mathrm{~h}$. (a) The cells were added with Cy-COX $(5 \mu \mathrm{M})$ before imaging and incubated for $60 \mathrm{~min}$ as the control group. TGF- $\beta 1\left(5 \mathrm{ng} \mathrm{mL}{ }^{-1}\right)$ stimulated these two cells for $24 \mathrm{~h}$ and $72 \mathrm{~h}$ to establish early and late cell models of pulmonary fibrosis. (b) The control group, TGF- $\beta 1_{24 \mathrm{~h}}$, and TGF- $\beta 1_{72 \mathrm{~h}}$ groups were analyzed by flow cytometry. (c) Quantification of the mean fluorescence intensity of images (a). (d) The expression of COX-2 protein, collagen I protein, and $\alpha$-SMA protein in MRC-5 and RLE-6TN cells were analyzed by Western Blot experiments. GAPDH was chosen as the internal control. (e) Quantification of COX-2 protein. (f) Quantification of collagen I protein. (g) Quantification of $\alpha$-SMA protein. Data are displayed as mean \pm SD $(n=5)$. Scale bars: $20 \mu m$.

fluorescence intensity of cell imaging. The results of the bright field image of cell imaging in Fig. 3a can be viewed in Fig. S7 $(\mathrm{ESI} \dagger)$. As we all know, cells will have typical interstitial characteristics during pulmonary fibrosis. The process of pulmonary fibrosis involves fibroblast-myofibroblast transformation (FMT) and epithelial-mesenchymal transition (EMT), accompanied by an increase in collagen I protein and alpha-smooth muscle actin ( $\alpha$-SMA) protein, ${ }^{38,39}$ Therefore, we used western blot analysis to detect the expression of collagen I and $\alpha$-SMA protein to indicate the progression of pulmonary fibrosis (Fig. 3d). The change of COX-2 concentration was further verified by western blot experiments (Fig. 3d). COX-2 protein increased after $24 \mathrm{~h}$ of TGF- $\beta 1$ stimulation and decreased after stimulation for $72 \mathrm{~h}$. Collagen I protein and $\alpha$-SMA protein increased with stimulation time, indicating that the severity of pulmonary fibrosis also increased with stimulation time. The above results indicated that COX-2 evidently increased after $24 \mathrm{~h}$ of TGF- $\beta 1$ stimulation, and COX- 2 extremely reduced after stimulation for $72 \mathrm{~h}$. These data certified that the intracellular COX-2 level had a close correlation with pulmonary fibrosis.

3.6 The protective effect of COX-2 in pulmonary fibrosis cell models

We have already discussed the changes of COX-2 in different time periods of TGF- $\beta 1$ stimulation. These changes in COX-2 concentration indicated that intracellular COX-2 played an important role in cellular self-protection during pulmonary fibrosis. We inferred that under short-term (24 h) TGF- $\beta 1$ stimulation, the cell self-protection mechanism responded quickly to cytokine stimulation. However, with the progress of pulmonary fibrosis, the long-term ( $72 \mathrm{~h}$ ) stimulation by TGF- $\beta 1$ was beyond the ability of the cell self-protection. Considering the protective effect of COX-2 in pulmonary fibrosis, in the TGF- $\beta 1$ group, MRC- 5 and RLE-6TN cells were stimulated with TGF- $\beta 1$ for $72 \mathrm{~h}$ to establish the required pulmonary fibrosis cell model. All imaging results were recorded using laser 

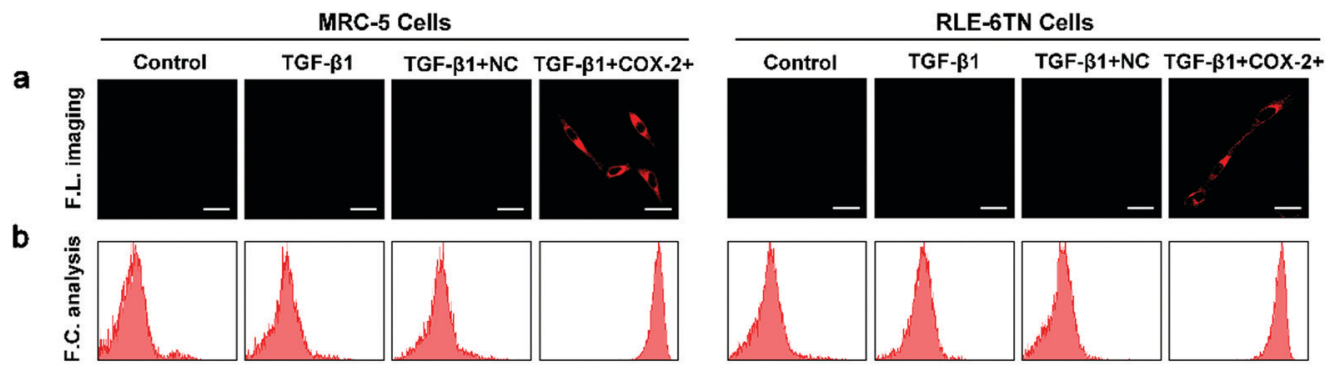

c

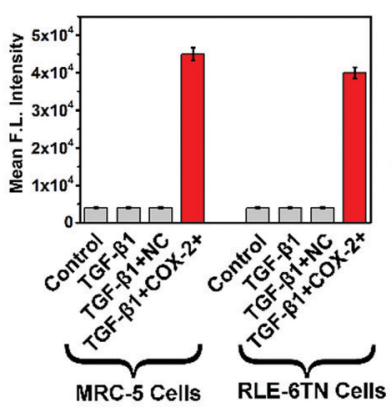

e

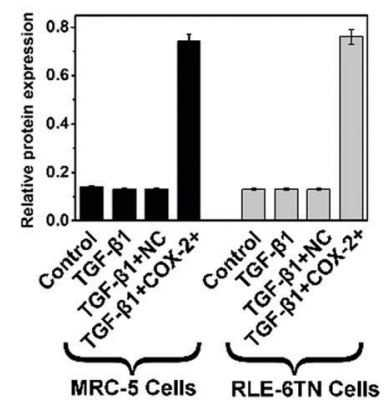

d

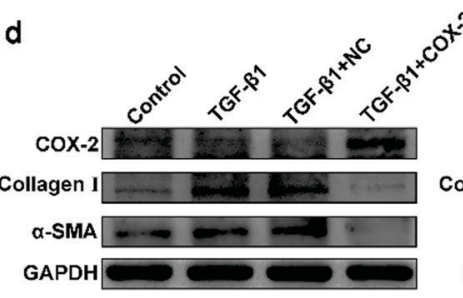

MRC-5 Cells

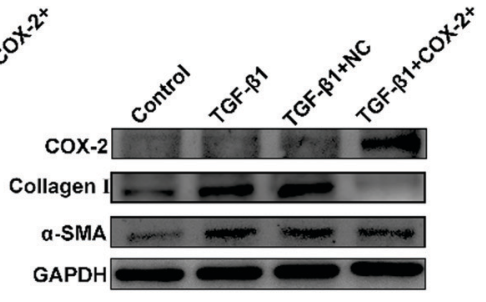

RLE-6TN Cells
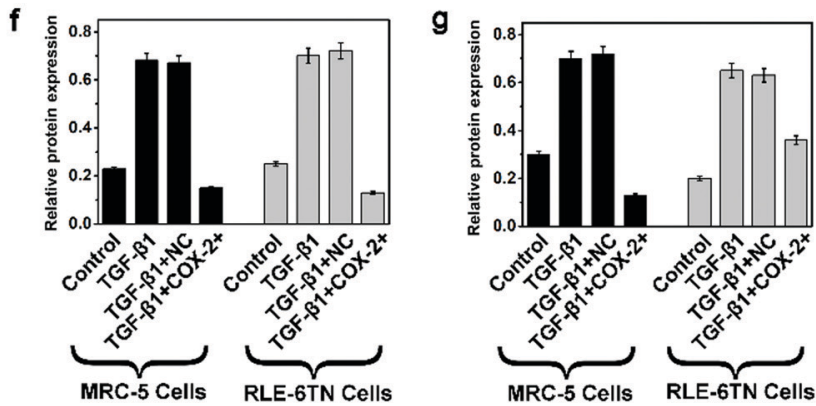

Fig. 4 Evaluation of the protective effect of COX-2 in pulmonary fibrosis. (a) MRC- 5 and RLE-6TN cells were added with Cy-COX (5 $\mu$ M) before imaging and incubated for $60 \mathrm{~min}$ as the control group. The TGF- $\beta 1$ group was stimulated with TGF- $\beta 1\left(5 \mathrm{ng} \mathrm{mL}{ }^{-1}\right)$ for $72 \mathrm{~h}$ to establish the required pulmonary fibrosis cell model. TGF- $\beta 1$ + BP group was first transfected with pIRES2-EGFP, and the TGF- $\beta 1+$ COX- $2+$ group was first transfected with pIRES2-EGFPPTGS2 to overexpress COX-2, and the two groups were then treated the same way as the TGF- $\beta 1$ group to create cell models. (b) Fluorescence intensities in MRC- 5 and RLE-6TN cells were analyzed by flow cytometry in the Control, TGF- $\beta 1$, TGF- $\beta 1+N C$, and TGF- $\beta 1+$ COX- $2+$ groups. (c) Quantification of the mean fluorescence intensity of images (a). (d) The expression of COX-2 protein, collagen I, and $\alpha$-SMA protein in MRC-5 and RLE-6TN cells was analyzed by Western Blot experiment. GAPDH was chosen as the internal control. (e) Quantification of COX-2 protein. (f) Quantification of collagen I protein. (g) Quantification of $\alpha$-SMA protein. Data are displayed as mean \pm SD $(n=5)$. Scale bars: $20 \mu \mathrm{m}$.

confocal microscopy. As Fig. 4a displayed, the cell images in the TGF- $\beta 1+$ COX- $2+$ group showed a significant increase in fluorescence intensity because of the high levels of COX-2 in cells. However, the Control, TGF- $\beta 1$, and TGF- $\beta 1+$ NC groups had almost no fluorescence, suggesting that the cells in these groups contained low concentrations of COX-2. Flow cytometry results further confirmed the above confocal imaging results (Fig. 4b). Fig. 4c displayed the mean fluorescence intensity of cell imaging. The results of the bright field image of cell imaging in Fig. 4a can be viewed in Fig. S8 (ESI $\dagger$ ). As illustrated in Fig. $4 \mathrm{~d}, \mathrm{WB}$ results showed that COX-2 protein increased significantly in the TGF- $\beta 1+\mathrm{COX}-2$ group, while the other groups almost did not express the COX-2 protein. Compared to the control group, the collagen I protein and $\alpha$-SMA protein in the TGF- $\beta 1$ and TGF- $\beta 1$ + NC groups were obviously increased, suggesting an increase in the degree of pulmonary fibrosis. However, the collagen I protein and $\alpha$-SMA protein in the TGF- $\beta 1+$ COX-2+ group were significantly reduced compared to TGF- $\beta 1$ and TGF- $\beta 1+$ BP groups. This indicated that COX-2 had a protective effect on pulmonary fibrosis, and the increase in COX-2 levels can significantly relieve the severity of pulmonary fibrosis.

\subsection{Imaging COX-2 in the pulmonary fibrosis mice models}

The successful application of the cell imaging experiment has greatly encouraged us to conduct further imaging experiments in vivo in mice. C57BL/6 mice were infused with bleomycin via trachea before imaging. To evaluate the level fluctuations of COX-2 in the development of pulmonary fibrosis, we divided the mice into five groups according to the number of stimulation days: $0,7,14,21$, and 28 days. In order to detect the changes of COX-2 in pulmonary fibrosis in vivo, we instilled the probe Cy-COX into the lungs through the trachea and performed fluorescence imaging in vivo after $30 \mathrm{~min}$. As presented in Fig. 5a, as the stimulation time increased, the fluorescence intensity gradually increased, reaching the maximum fluorescence 


\section{a}
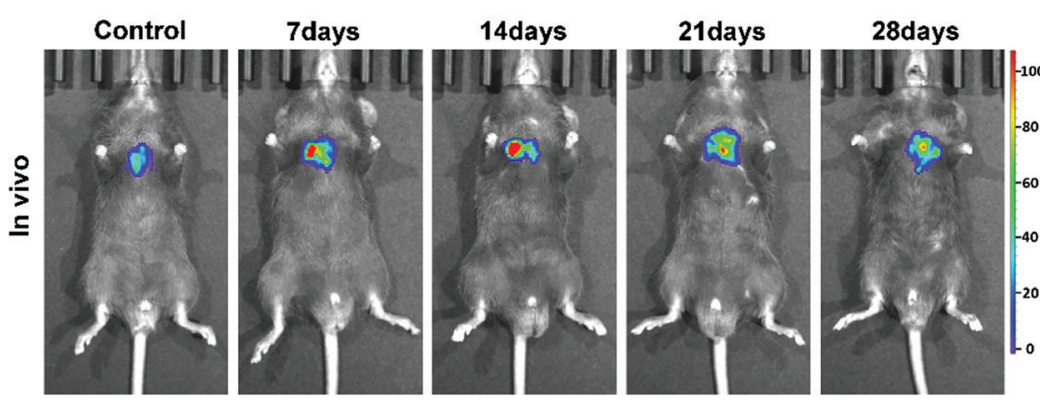

c

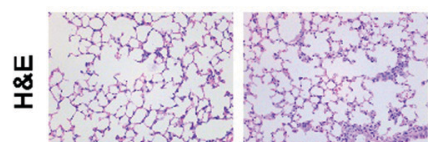

d

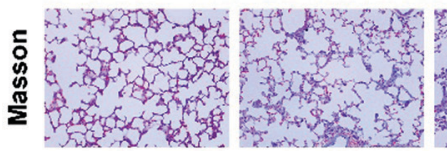

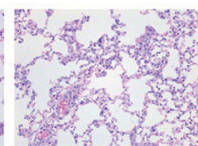
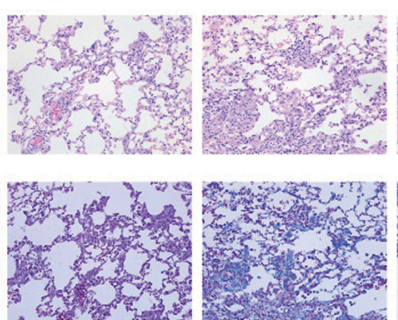
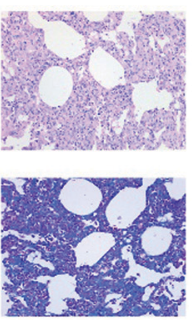
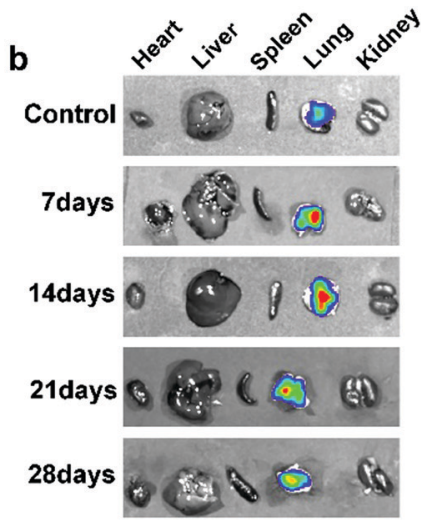

e

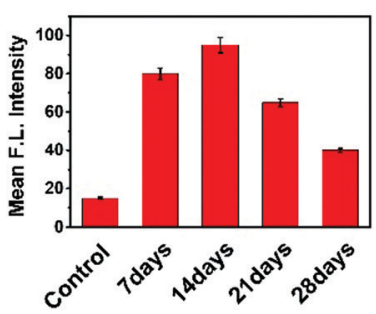

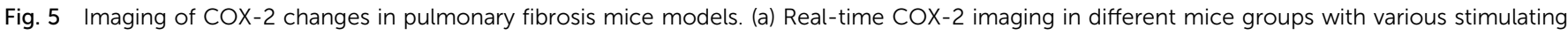

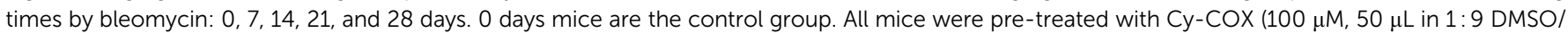

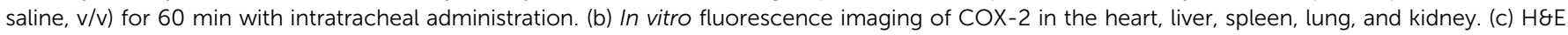

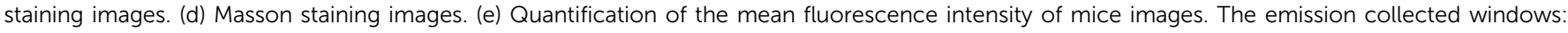
$750-800 \mathrm{~nm}, \lambda_{\mathrm{ex}}=650 \mathrm{~nm}$. Data are displayed as mean $\pm \mathrm{SD}(n=5)$.

intensity on the 14th day, and then gradually decreased until the minimum fluorescence intensity on the 28th day, which was still stronger than the control group. We hypothesized that although there was residual COX-2, its levels were not enough to prevent the development of pulmonary fibrosis. The mechanisms of COX-2 reduction in the process of pulmonary fibrosis in previous experiments have shown that the low acetylation of histone led to the reduction of COX-2 expression, ${ }^{40}$ and other studies have shown that the hypermethylation of chromosome 8 open reading frame 4 (c8orf4) led to the decreased ability of fibroblasts in fibrotic lung to upregulate COX-2. ${ }^{41}$ However, the specific mechanism of COX-2 reduction in pulmonary fibrosis can be further proved by our probe in future experiments. Fluorescence imaging of isolated organs showed obvious fluorescence signals in the lungs, but no fluorescence signals in other organs (Fig. 5b). Fig. 5e displayed the mean fluorescence intensity of mice imaging. The establishment of mice models of pulmonary fibrosis and the change of pulmonary fibrosis progression were presented by $\mathrm{H} \& \mathrm{E}$ and Masson staining (Fig. 5c and $\mathrm{d}$ ). The above experimental results proved the close relationship between COX-2 and pulmonary fibrosis. The probe Cy-COX has also been successfully used as a tool for imaging COX-2 level fluctuations in the pulmonary fibrosis mice models.

\section{Conclusions}

In general, we have successfully synthesized a novel NIR fluorescent probe Cy-COX to detect COX-2 with high selectivity, and it was used to evaluate the fluctuation of COX-2 levels in pulmonary fibrosis models. The probe was successfully applied in the detection of COX-2 and evaluation of the protective effect of COX-2 in fibrosis cell models. We also visualized the changes in COX-2 levels in early and late stages in mice models of pulmonary fibrosis. These results suggested that COX-2 played a role in the inflammatory response of alveolar cells and the early stage of pulmonary fibrosis through high expression. However, in the late stage of pulmonary fibrosis, the increase of COX-2 was inhibited, and the severity of pulmonary fibrosis increased. Therefore, probe Cy-COX has great potential in predicting the progression of early pulmonary fibrosis and evaluating effective treatment.

\section{Conflicts of interest}

There are no conflicts to declare.

\section{Acknowledgements}

We thank the National Natural Science Foundation of China (No. 81573393, 21804010, 21976209, 21976105, 81870001, 21778026), the science and technology innovation development plan of Yantai of China (No. 2020MSGY113), the Research Initiation Fund of Binzhou Medical University (Grant No. BY2019KYQD39, BY2020KYQD01) and Taishan Scholar Project Special Funding (No. ts20190962).

\section{References}

1 S. European Resp and S. Amer Thoracic, Am. J. Respir. Crit. Care Med., 2000, 161, 646-664. 
2 I. O. Rosas, P. F. Dellaripa, D. J. Lederer, D. Khanna, L. R. Young and F. J. Martinez, Ann. Am. Thorac. Soc., 2014, 11(Suppl 3), S169-S177.

3 C. Vancheri, M. Failla, N. Crimi and G. Raghu, Eur. Respir. J., 2010, 35, 496-504.

4 W. R. Coward, G. Saini and G. Jenkins, Journal, 2010, 4, 367-388.

5 P. J. Wolters, H. R. Collard and K. D. Jones, Ann. Rev. Pathol. J. Article, 2014, 9, 157.

6 G. Raghu, B. Rochwerg, Y. Zhang, C. A. C. Garcia, A. Azuma, J. Behr, J. L. Brozek, H. R. Collard, W. Cunningham, S. Homma, T. Johkoh, F. J. Martinez, J. Myers, S. L. Protzko, L. Richeldi, D. Rind, M. Selman, A. Theodore, A. U. Wells, H. Hoogsteden, H. J. Schuenemann, Ats, Alat, Ers, Jrs, s. European Respiratory, S. American Thoracic, S. Japanese Respiratory and A. Latin American Thoracic, Am. J. Respir. Crit. Care Med., 2015, 192, E3-E19.

7 M. E. Turini and R. N. DuBois, Annu. Rev. Med., 2002, 53, 35-57.

8 W. L. Smith and D. L. Dewitt, Adv. Immunol., 1996, 62(62), 167-215.

9 B. Hinz and K. Brune, J. Pharmacol. Exp. Ther., 2002, 300, 367-375.

10 S. Hunot, M. Vila, P. Teismann, R. J. Davis, E. C. Hirsch, S. Przedborski, P. Rakic and R. A. Flavell, Proc. Natl. Acad. Sci. U. S. A., 2004, 101, 665-670.

11 G. Y. Park and J. W. Christman, Am. J. Physiol.: Lung Cell. Mol. Physiol., 2006, 290, L797-L805.

12 K. Q. Hu, Prostaglandins, Leukotrienes Essent. Fatty Acids, 2003, 69, 329-337.

13 D. G. Menter, R. L. Schilsky and R. N. DuBois, Clin. Cancer Res., 2010, 16, 1384-1390.

14 R. N. Dubois, S. B. Abramson, L. J. Crofford, R. A. Gupta, L. S. Simon, L. B. A. V. D. Putte and P. E. Lipsky, FASEB J., 1998, 12, 1063-1073.

15 J. Wilborn, L. J. Crofford, M. D. Burdick, S. L. Kunkel, R. M. Strieter and M. Petersgolden, J. Clin. Invest., 1995, 95, 1861-1868.

16 S. Huang, S. H. Wettlaufer, C. Hogaboam, D. M. Aronoff and M. Peters-Golden, Am. J. Physiol.: Lung Cell. Mol. Physiol., 2007, 292, L405-L413.

17 C. B. Keerthisingam, R. G. Jenkins, N. K. Harrison, N. A. Hernandez-Rodriguez, H. Booth, G. J. Laurent, S. L. Hart, M. L. Foster and R. J. McAnulty, Am. J. Pathol., 2001, 158, 1411-1422.

18 J. C. Bonner, A. B. Rice, J. L. Ingram, C. R. Moomaw, A. Nyska, A. Bradbury, A. R. Sessoms, P. C. Chulada, D. L. Morgan, D. C. Zeldin and R. Langenbach, Am. J. Pathol., 2002, 161, 459-470.

19 R. J. Hodges, R. G. Jenkins, C. P. D. Wheeler-Jones, D. M. Copeman, S. E. Bottoms, G. J. Bellingan, C. B. Nanthakumar, G. J. Laurent, S. L. Hart, M. L. Foster and R. J. McAnulty, Am. J. Pathol., 2004, 165, 1663-1676.
20 Y.-H. Hsieh, F.-H. Chu, Y.-S. Wang, S.-C. Chien, S.-T. Chang, J.-F. Shaw, C.-Y. Chen, W.-W. Hsiao, Y.-H. Kuo and S.-Y. Wang, J. Agric. Food Chem., 2010, 58, 3153-3158.

21 M. Bardagi, D. Fondevila and L. Ferrer, J. Comp. Pathol., 2012, 146, 11-17.

22 S. Cai, Y.-x. Zhang, K. Han and Y.-q. Ding, Arch. Gynecol. Obstet., 2017, 296, 93-98.

23 M. Gao, F. B. Yu, C. J. Lv, J. Choo and L. X. Chen, Chem. Soc. Rev., 2017, 46, 2237-2271.

24 Y. M. Yang, Q. Zhao, W. Feng and F. Y. Li, Chem. Rev., 2013, 113, 192-270.

25 L. Yuan, W. Y. Lin, K. B. Zheng, L. W. He and W. M. Huang, Chem. Soc. Rev., 2013, 42, 622-661.

26 S. A. Hilderbrand and R. Weissleder, Curr. Opin. Chem. Biol., 2010, 14, 71-79.

27 D. D. Nolting, J. C. Gore and W. Pham, Curr. Org. Synth., 2011, 8, 521-534.

28 V. Marx, Nat. Methods, 2014, 11, 717-720.

29 M. A. Pysz, S. S. Gambhir and J. K. Willmann, Clin. Radiol., 2010, 65, 500-516.

30 J. V. Frangioni, Curr. Opin. Chem. Biol., 2003, 7, 626-634.

31 H. Zhang, J. L. Fan, K. Wang, J. Li, C. X. Wang, Y. M. Nie, T. Jiang, H. Y. Mu, X. J. Peng and K. Jiang, Anal. Chem., 2014, 86, 9131-9138.

32 X. Z. Cao, T. Gao, J. Dong, X. C. Jiang, H. Zou, T. T. Liu, K. D. Yu and W. B. Zeng, New J. Chem., 2019, 43, 7874-7880.

33 H. Zhang, J. L. Fan, J. Y. Wang, S. Z. Zhang, B. R. Dou and X. J. Peng, J. Am. Chem. Soc., 2013, 135, 11663-11669.

34 B. Gurram, S. Z. Zhang, M. Li, H. D. Li, Y. H. Xie, H. Y. Cui, J. J. Du, J. L. Fan, J. Y. Wang and X. J. Peng, Anal. Chem., 2018, 90, 5187-5193.

35 H. Zhang, J. L. Fan, J. Y. Wang, B. R. Dou, F. Zhou, J. F. Cao, J. L. Qu, Z. Cao, W. J. Zhao and X. J. Peng, J. Am. Chem. Soc., 2013, 135, 17469-17475.

36 M. J. Uddin, B. C. Crews, K. Ghebreselasie and L. J. Marnett, Bioconjugate Chem., 2013, 24, 712-723.

37 M. J. Uddin, B. C. Crews, A. L. Blobaum, P. J. Kingsley, D. L. Gorden, J. O. McIntyre, L. M. Matrisian, K. Subbaramaiah, A. J. Dannenberg, D. W. Piston and L. J. Marnett, Cancer Res., 2010, 70, 3618-3627.

38 M. Rojas, M. Gabasa, D. Royo, M. Molina-Molina, J. RocaFerrer, L. Pujols, C. Picado, A. Xaubet and J. Pereda, PLoS One, 2013, 8, e65445.

39 H. Kage and Z. Borok, Curr. Opin. Pulm. Med., 2012, 18, 517-523.

40 W. R. Coward, K. Watts, C. A. Feghali-Bostwick, A. Knox and L. Pang, Mol. Cell. Biol., 2009, 29, 4325-4339.

41 I. C. Evans, J. L. Barnes, I. M. Garner, D. R. Pearce, T. M. Maher, S. Xu, E. A. Renzoni, A. U. Wells, C. P. Denton, G. J. Laurent, D. J. Abraham and R. J. McAnulty, Clin. Sci., 2016, 130, 575-586. 